\title{
Metabolic response to water shortage in an isolated feral sheep population
}

\author{
Omar R. Prado a , Erika I. Arias ${ }^{\mathrm{b}}$, María D. Carrillo ${ }^{\mathrm{a}}$, Juan R. Hernández ${ }^{\mathrm{a}}$, Arturo C. García ${ }^{\mathrm{a}}$
}

\begin{abstract}
To establish metabolic responses for biochemical analytes related to freshwater shortage adaptation, a total of 376 blood samples were collected from feral sheep at the Socorro Island, Revillagigedo Archipelago. Comparisons were made between four sampling periods with repeated measurements at 0,7,14, and $21 \mathrm{~d}$ (94 blood serums: 84 females and 10 males). During the first week, the sheep received daily water ad libitum. During the second and third week, the sheep received $60 \%$ daily water in relation to the first 7 days intake. Analysis of variance was used to compare the mean values between sampling days. Stepwise regression analysis was used to evaluate the relationships between the biochemical analytes. The glucose (GLU), total cholesterol (COL-T), triglycerides (TAG), urea, albumin (ALB), total protein (PROT-T), sodium ion $\left(\mathrm{Na}^{+}\right)$, creatine kinase $(\mathrm{CK})$, arginine vasopressin (AVP), and aldosterone (Aldo), were determined. With the exception of GLU, the COL-T, TAG, urea, ALB, PROT-T, Na ${ }^{+}, \mathrm{CK}, \mathrm{AVP}_{\text {, }}$ and Aldo showed differences between sampling days with the higher values corresponding to $14 \mathrm{~d}$ with limited water intake. Negative correlations $(P<0.05)$ between ALB with COL-T and TAG, were quantified. Positive correlations $(P<0.05)$ between COL-T with TAG, and Aldo; between urea with PROT-T, between CK with ALB and PROT-T, between AVP with COL-T, TAG, urea, PROT-T and Aldo, and between Aldo with $\mathrm{Na}^{+}$, were quantified. Results could help improve the accuracy of metabolic profiles used as a tool for evaluating dehydration indicators and to describe the physiological mechanisms employed by feral sheep to cope with limited availability of freshwater.

Key words: blood biochemistry, metabolic profile, feral sheep, resilience to water shortage.
\end{abstract}

\section{INTRODUCTION}

The limited availability of freshwater for livestock has been a limiting factor in ruminant physiology and productivity (Vosooghi-Postindoz et al 2018). Fortunately, small ruminants have several adaptive mechanisms to efficiently use their physiological water reserves (Casamassima et al 2016), in this way overcoming the stresses caused by water shortage and dehydration (Berihulay et al 2019). These mechanisms include decreasing body water losses in the urine and faeces. The urine water losses can be reduced by promoting water reabsorption at renal tubules (Rotondo et al 2016, Trepiccione et al 2019), whereas faecal water losses can be decreased by promoting water absorption at gastrointestinal level (Ames et al 2019). However, in both cases, the serum volume decreases due to the water uptake by cells (Trepiccione et al 2019). Hyperosmolality due to increased solute concentrations is, thus, commonly detected in water-restricted sheep (Pratt et al 2016). A remarkable example of these adaptive mechanisms started with the introduction and abandonment of 100 sheep (Ovis aries Linnaeus, 1758) by Australian settlers to the Socorro Island of the Revillagigedo Archipelago in 1869 (Salas de León et al 2015). In the absence of handling, sheep became feral and adapted to the insular environment (Hernández et al 2017). The prolonged isolation allowed the

Received: 24.05 .2020 .

Accepted: 20.08.2020.

aFacultad de Medicina Veterinaria y Zootecnia, Universidad de Colima, Tecomán Colima, México.

${ }^{b}$ Maestría en Ciencias Agropecuarias, Universidad Autónoma Metropolitana, Ciudad de México, México.

*Corresponding author: AC García Casillas; cesargarciacasillas@ hotmail.com sheep population to develop traits adapted to the food and freshwater scarcity (Pickering et al 2013). In the absence of natural enemies, the sheep population grew to be about 5,000 individuals and they became the main disturbance agent of the island's ecological conditions (Hernández et al 2017). Thus, the Chamber of Deputies in Mexico approved the extermination of the feral sheep on the island (Ortiz et al 2016). To preserve the valuable germplasm of the Socorro Island sheep population, the Faculty of Veterinary Medicine of the University of Colima and the National Council of Science and Technology carried out a program of extraction and recovery (Hernández et al 2017). A thorough understanding of the adaptive physiological mechanisms to cope with limited water availability should be the starting point of all efforts to improve the resilience of domestic sheep to climate change. In this sense, the glucose (GLU), total cholesterol (COL-T), triglycerides (TAG), urea, albumin (ALB), total protein (PROT-T), sodium ion $\left(\mathrm{Na}^{+}\right)$, creatine kinase (CK), arginine vasopressin or antidiuretic hormone (AVP), and aldosterone (Aldo) are considered good indicators of dehydration. Thus, this study aimed to establish metabolic responses for biochemical analytes related to freshwater shortage adaptation, in feral sheep at the Socorro Island, Revillagigedo Archipelago, Mexico.

\section{MATERIAL AND METHODS}

\section{ANIMALS}

This experiment followed institutional and national guidelines for the care and use of animals. All experimental procedures were approved by the Committee of Ethical Review at Colima University (protocol approval number: 06/19; experimental period: October 2019). The animals 
belong to the feral sheep extraction and recovery program of the Socorro Island of the Revillagigedo Archipelago. The Socorro Island (figure 1), is a tropical volcanic island located in the Pacific Ocean (18 $42^{\prime} 28^{\prime \prime}$ N, $111^{\circ} 02^{\prime} 49^{\prime}$ ' W), $540 \mathrm{~km}$ south of Cabo San Lucas in Baja California Sur and $720 \mathrm{~km}$ west of Manzanillo, Colima, Mexico. It has an area of $132 \mathrm{~km}^{2}$ and a maximum elevation of $1040 \mathrm{~m}$. Climate is warm, sub-humid (Köppen Cfb) (Peel et al 2007). The average temperature is $22-27.5^{\circ} \mathrm{C}$. It is located in the path of tropical cyclones that occur from June to November with an average of 2.75 events/year, with precipitation of more than $400 \mathrm{~mm}$ during the season.

Currently, the livestock inventory is located on the animal husbandry experimental unit at the Faculty of Veterinary Medicine, University of Colima, Tecoman, Colima, Mexico (1856’53” N; 103 $\left.{ }^{\circ} 53^{\prime} 50^{\prime \prime} \mathrm{W}\right)$. The climate is warm, sub-humid (Köppen $\mathrm{Cfb}$ ) with summer rains (Peel et al 2007). The average temperature is $26^{\circ} \mathrm{C}$ with precipitation of $750 \mathrm{~mm} /$ year (Hernández et al 2017). The study was carried out by sampling and analysing 376 blood serums from total livestock inventory ( 94 feral sheep in maintenance: 84 females and 10 males), with initial body weight (average \pm S.D.) of $45 \pm 4 \mathrm{~kg}$ and $60 \pm 6$ $\mathrm{kg}$, respectively, body condition score $(2.20 \pm 0.8)$ and age (14 \pm 2 months). Feeding conditions of sheep in the island were maintained at the experimental housing unit. Animals were able to graze Conocarpus scrub, Croton masonii scrub, and Pteridium-Dononaea scrub, introduced from Socorro Island (Flores et al 2009). Previous to the study, the herd was dewormed with Ivermectin (1 $\mathrm{mL} / 25 \mathrm{~kg}$ of live weight subcutaneously) followed by immunisations against Clostridium, Pasteurella multocida and Mannheimia haemolytica (BOBACT 8. SAGARPA B-0273-111; Intervet., Mexico City, Mexico) $2.5 \mathrm{~mL} /$ animal subcutaneously.

\section{EXPERIMENTAL PROTOCOL}

Comparisons were made between four sampling periods with repeated measurements at $0,7,14$, and $21 \mathrm{~d}$. During the first week, the sheep received daily water ad libitum. To determine the quantity of water for the second and third weeks, water intake was recorded during the first week. In the experiment, the sheep received $60 \%$ daily water in relation to the first 7 days intake; this was achieved by restricting water intake by $40 \%$ compared to the intake of the first week.

\section{BLOOD COLLECTION AND DETERMINATION OF ANALYTES}

Blood samples were collected by puncture of the jugular vein before morning feeding at $0,7,14$, and $21 \mathrm{~d}$ with restricting water intake (figure 2).

For GLU, COL-T, TAG, urea, ALB, PROT-T, $\mathrm{Na}^{+}$, and $\mathrm{CK}$ analysis, $8.5 \mathrm{~mL}$ of blood were collected into vacuum tubes with clot activator and serum separator gel (BD Vacutainer 367988; Becton-Dickinson Co., Franklin Lakes, United States). For AVP and Aldo, additional samples of $5 \mathrm{~mL}$ of blood were collected into vacuum tubes with EDTA-K $_{3}$ (BD Vacutainer 366352; Becton-Dickinson Co., Franklin Lakes, United States). To collect serum, blood samples were centrifuged at $1500 \times \mathrm{g}$ for $10 \mathrm{~min}$ by using a portable centrifuge (Porta-Spin C828; UNICO, Dayton, United States). Serum samples were separated using
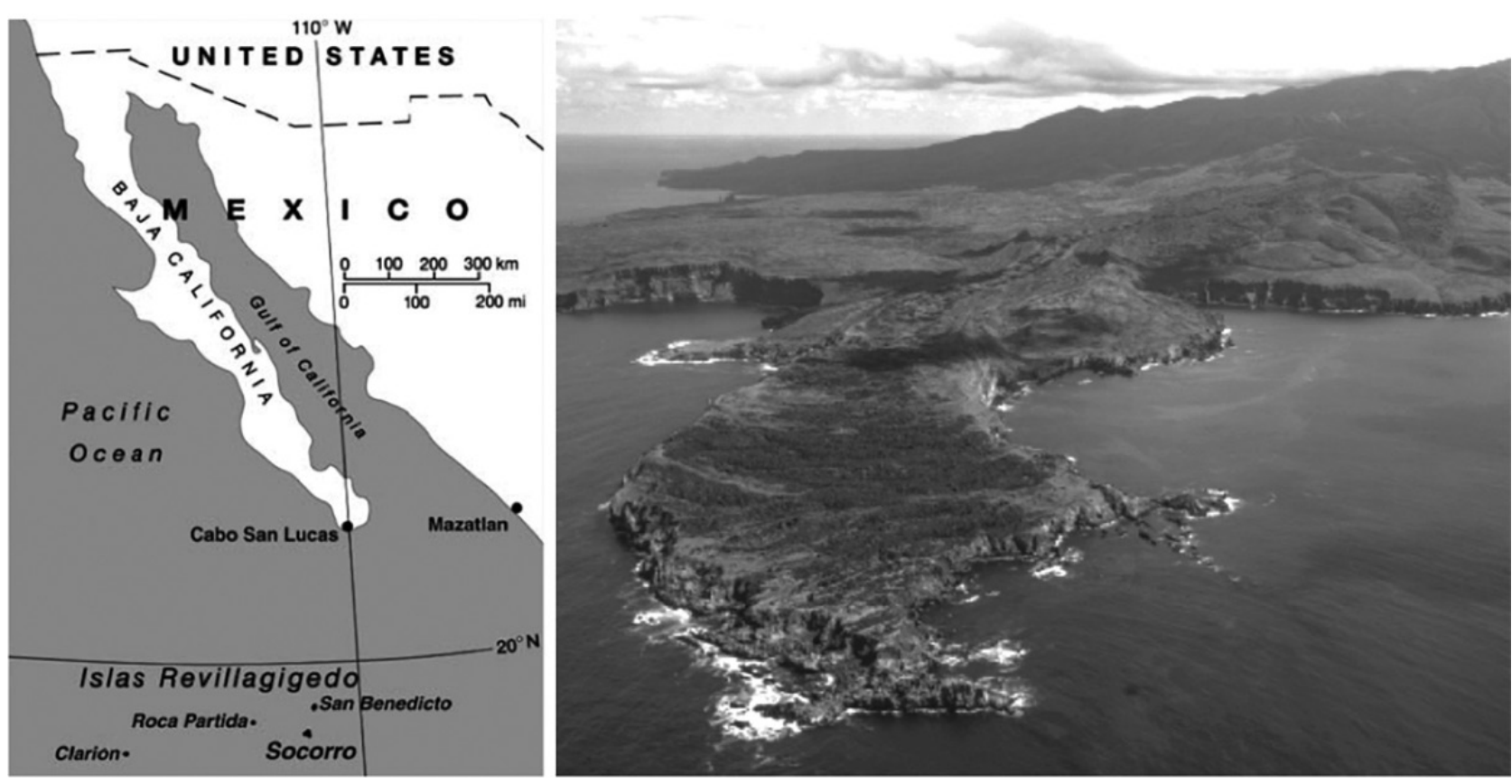

Figure 1. Location of the Socorro Island, Revillagigedo Archipelago, $720 \mathrm{~km}$ west of Manzanillo, Colima. 

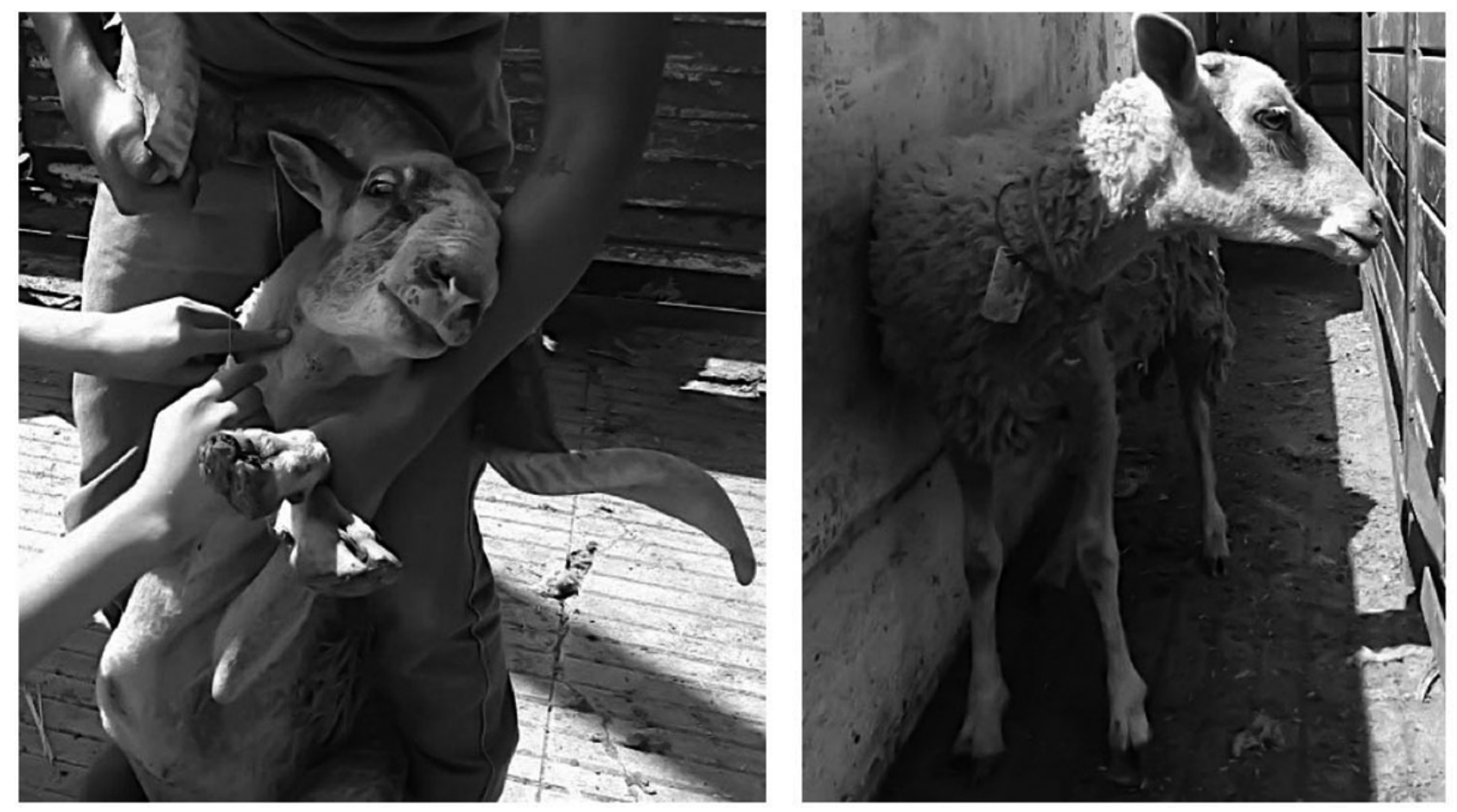

Figure 2. Feral sheep from the Socorro Island, Revillagigedo Archipelago.

$1.5 \mathrm{~mL}$ tubes with lid (Tubes Safe-Lock 3810X; Eppendorf., Madrid, Spain) and transported at $4{ }^{\circ} \mathrm{C}$ in a portable cooler (Thermoelectric Cooler Car/Home M5644-710; Coleman Company, Kansas, United States) to the clinical laboratories at the Autonomous Metropolitan University and the University of Colima, where they were frozen at $-20{ }^{\circ} \mathrm{C}$ until analysis. The concentration of each analyte was determined with a UV-Vis double beam spectrophotometer (Biochemistry Analyzer; KONTROLab, Guidonia, Italy) and the hormones were determined with a gamma counter (PC-RIA MAS; Stretec, Germany). Biochemical analytes, analytical method for each parameter, units in which the results were expressed, and corresponding commercial reagents, are described in (table 1).

Precision and reliability of the techniques were controlled using lyophilised control serum (SPINTROL NORMAL 1002100; Spinreact, Girona, Spain) and Assayed MultiSera AL 1027 (Randox Laboratories, Northern Ireland, United Kingdom). Hemolysis of serum was recorded on a qualitative scale of 0 (none) to 3 (dark). Samples showing haemolysis scores of 2 and above constituted less than $1 \%$ of all samples and did not introduce a significant bias in any of the tested models; thus, the influence of serum haemolysis was ignored.

\section{STATISTICAL ANALYSIS}

The data were described by average and S.D., and they were tested for normal distribution (Shapiro-Wilk test). The linear relationships between the biochemical analytes were identified by the use of a Pearson Correlation Coefficient matrix, and Stepwise regression analysis (PROC REG, SAS, System, v. 8.2, Cary, NC). Analysis of variance was used to compare the mean values between sampling days. A multiple comparison test of Tukey was performed when the effect of the sampling day was found to be significant $(P<0.05)$. A diagnosis for outlier values was performed using robust multivariate outlier detection (OUTLIER; SAS, 2001). This macro calculates the robust Mahalanobis distance for each observation ${ }^{1}$. The following model was tested:

$$
d_{m}(\mathrm{x}, \overline{\mathrm{x}})=\sqrt{(\mathrm{x}-\overline{\mathrm{x}}) \sum_{x}^{-1}(\mathrm{x}-\overline{\mathrm{x}})}
$$

Where:

$d_{m}(\mathrm{x}, \overline{\mathrm{x}})=$ robust Mahalanobis distance;

$\mathrm{x}=$ vector of the observation;

$\overline{\mathrm{x}}=$ vector average of the observations; and

$\Sigma_{x}^{-1}=$ variance-covariance matrix of the observations.

Regression diagnosis for main assumptions was performed (PROC UNIVARIATE; SAS, 2001). The linear functional form was visually checked by a normal plot. Shapiro-Wilk test was used to check the normality of residuals. Homoscedasticity was checked by plotting

\footnotetext{
http://www.datavis.ca/sasmac/outlier.html, accessed May 10, 2020.
} 
Table 1. Biochemical analytes, units, analytical methods, and corresponding commercial reagents.

\begin{tabular}{lccc}
\hline Analyte $^{*}$ & Unit & Method & Reagent \\
\hline Glucose (GLU) & $\mathrm{mM}$ & Colorimetric. Trinder $^{\mathrm{a}}$ & $1001190^{1}$ \\
Total cholesterol (COL-T) & $\mathrm{mM}$ & Colorimetric. Liquid $^{\mathrm{b}}$ & $41020^{1}$ \\
Triglycerides (TAG) & $\mathrm{mM}$ & Colorimetric. Liquid $^{\mathrm{c}}$ & $41032^{1}$ \\
Urea & $\mathrm{mM}$ & Enzymatic $^{\mathrm{d}}$ & $1001333^{1}$ \\
Albumin (ALB) & $\mathrm{g} / \mathrm{dL}$ & Colorimetric. Bromocresol green $^{1}$ & $1001020^{1}$ \\
Total protein (PROT-T) & $\mathrm{g} / \mathrm{dL}$ & Colorimetric. Biuret & $1001291^{1}$ \\
Sodium ion (Na & $\mathrm{mM}$ & Enzymatic. Galactosidase & $1001385^{1}$ \\
Creatine kinase (CK) & $\mathrm{U} / \mathrm{L}$ & Enzymatic & $41250^{1}$ \\
Arginine vasopressin (AVP) & $\mathrm{pg} / \mathrm{mL}$ & Radioimmunoassay $^{\mathrm{f}}$ & KIPERB3192 $^{2}$ \\
Aldosterone (Aldo) & $\mathrm{pg} / \mathrm{mL}$ & Radioimmunoassay $^{\mathrm{g}}$ & KIPZ0102 $^{2}$ \\
\hline
\end{tabular}

${ }^{*}$ Official abbreviation of the International Union of Pure and Applied Chemistry (IUPAC); ${ }^{\mathrm{a}}$ Glucose Oxidase-Peroxidase; ${ }^{\mathrm{b}} \mathrm{Cholesterol} \mathrm{Oxidase-Peroxidase;}$

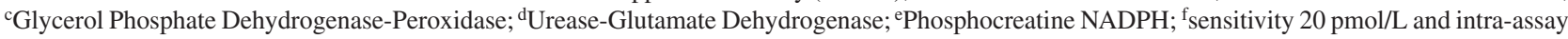
and inter-assay coefficient of variations were $5.6 \%$ and $6.1 \%$ respectively; ${ }^{\mathrm{g}}$ sensitivity $6 \mathrm{pg} / \mathrm{mL}$ and intra-assay and inter-assay coefficient of variations were $9.5 \%$ and $10.4 \%$ respectively; ${ }^{1}$ Spinreact, Girona, Spain; ${ }^{2}$ DIAsource ImmunoAssays, Ottignies-Louvain-la-Neuve, Belgium.

residual versus predicted values, and the Durbin-Watson test was employed to check for error uncorrelation.

\section{RESULTS}

The reference value, descriptive statistics for GLU, COL-T, TAG, urea, ALB, PROT-T, $\mathrm{Na}^{+}$, CK, AVP, Aldo, and their comparison between sampling days with limited drinking water availability in feral sheep from Socorro Island, Revillagigedo Archipelago are shown in table 2.

As shown in table 2, the biochemical analytes quantified in feral sheep from Socorro Island, presented no differences between males and females. However, their concentrations were above the reference range of the sheep. Except for GLU, the serum concentration of the other biochemical analytes (combined males and females) showed differences $(P<0.05)$ between sampling days, with the higher values corresponding to $14 \mathrm{~d}$ with limited water intake. Negative correlations $(P<0.05)$ between ALB with COL-T and TAG, were quantified. Positive correlations $(P<0.05)$ between COL-T with TAG, and Aldo; between urea with PROT-T, between CK with ALB and PROT-T, between AVP with COL-T, TAG, urea, PROT-T and Aldo, and between Aldo with $\mathrm{Na}^{+}$, are shown in table 3 .

\section{DISCUSSION}

Assessment of biochemical analytes sensitive to water shortage revealed that feral sheep from Socorro Island exhibited changes in serum concentrations of COL-T, TAG, urea, ALB, PROT-T, $\mathrm{Na}^{+}, \mathrm{CK}, \mathrm{AVP}$, and Aldo under $60 \%$ water restriction. All sheep needed $14 \mathrm{~d}$ to adapt to the water shortage and the concentration of biochemical analytes was closer to the value recorded during the first week, at $21 \mathrm{~d}$. This drop in biochemical analytes concentration suggests adaption to drinking water shortage at the end of the experimentation period. When small ruminants become dehydrated during water restriction, the serum volume decreases due to water uptake by tissue cells (Trepiccione et al 2019). In this sense, the urea molecules generate osmotic traction of water in the urinary tract (Weiner et al 2015), as water moves from areas of low concentration to those of high concentration to dilute urea in urine (Weiner 2017). Small ruminants such as the Awassi sheep, a Middle Eastern breed, have the ability to decrease urine volume and increased urea concentration, after being deprived of water for $5 \mathrm{~d}$ (Jaber et al 2004). Under conditions of drinking water shortage, however, the kidneys function is altered in Marwari sheep (Kataria and Kataria 2007) with slower glomerular filtration and higher urea reabsorption (Weiner and Verlander 2016), leading to increased blood concentrations of CK and urea (Weiner et al 2015), but without affecting GLU concentration (Abdelatif et al 2010), results similar to those found in this study (table 2). Reduced serum volume also increases concentrations of certain biochemical analytes (Berihulay et al 2019), and forces sheep to activate physiological mechanisms to adapt to dehydration and cope with limited drinking water availability (Mengistu et al 2016). Comisana sheep, a central and northern Sicily breed, under $60 \%$ water restriction for $40 \mathrm{~d}$, increased their concentrations of ALB, COL-T, PROT-T, and TAG, without affecting your concentrations of GLU (Casamassima et al 2008). In another study by the same group, the Lacaune sheep, a South of France breed, under $60 \%$ water restriction for $28 \mathrm{~d}$, increased their concentrations of CK and PROT-T (Casamassima et al 2016). Hamadeh et al (2006) suggested that concentrations of ALB, COL-T, CK, PROT-T, and urea are influenced by the consumption of water. In their study, they offered water to Awassi sheep every $3 \mathrm{~d}$ under 
Table 2. Reference value, mean \pm standard deviation, and comparison of different biochemical analytes of feral sheep from the Socorro Island, Revillagigedo Archipelago, during restricting water intake.

\begin{tabular}{|c|c|c|c|}
\hline Analyte & Reference & Males $n=40$ blood serums $^{1}$ & Females $n=336$ blood serums ${ }^{1}$ \\
\hline Glucose (mM) & $3.80 \pm 0.33^{\dagger, \mathrm{a}}$ & $3.89 \pm 0.28^{\mathrm{a}}$ & $3.74 \pm 0.24^{\mathrm{a}}$ \\
\hline Total cholesterol (mM) & $1.66 \pm 0.31^{\dagger, \mathrm{a}}$ & $2.50 \pm 0.11^{\mathrm{b}}$ & $2.47 \pm 0.09^{b}$ \\
\hline Triglycerides (mM) & $0.33 \pm 0.01^{\S, \mathrm{a}}$ & $0.40 \pm 0.01^{\mathrm{b}}$ & $0.39 \pm 0.01^{b}$ \\
\hline Urea $(\mathrm{mM})$ & $7.70 \pm 0.43^{\S, a}$ & $8.63 \pm 0.06^{\mathrm{b}}$ & $8.61 \pm 0.05^{\mathrm{b}}$ \\
\hline Albumin (g/dL) & $2.70 \pm 0.11^{\dagger, \mathrm{a}}$ & $3.74 \pm 0.48^{b}$ & $3.51 \pm 0.37^{b}$ \\
\hline Total protein $(\mathrm{g} / \mathrm{dL})$ & $7.20 \pm 0.52^{\dagger, \mathrm{a}}$ & $8.87 \pm 0.37^{b}$ & $8.71 \pm 0.33^{b}$ \\
\hline Sodium ion (mM) & $141.5 \pm 4.1^{\dagger, \mathrm{a}}$ & $172.47 \pm 22.11^{\mathrm{b}}$ & $161.58 \pm 17.29^{b}$ \\
\hline Creatine kinase (U/L) & $10.3 \pm 1.6^{\dagger, \mathrm{a}}$ & $13.20 \pm 0.11^{\mathrm{b}}$ & $13.17 \pm 0.09^{b}$ \\
\hline Arginine vasopressin (pg/mL) & $3.30 \pm 1.37^{¥, \mathrm{a}}$ & $8.53 \pm 0.12^{\mathrm{b}}$ & $8.50 \pm 0.11^{b}$ \\
\hline Aldosterone (pg/mL) & $20.10 \pm 2.21^{\text {II,a }}$ & $28.14 \pm 1.15^{\mathrm{b}}$ & $27.82 \pm 1.01^{\mathrm{b}}$ \\
\hline
\end{tabular}

Combined males and females $n=94$ blood serums/sampling days Restricting water intake (d)

\begin{tabular}{|c|c|c|c|c|}
\hline & \\
\hline & 0 & 7 & 14 & 21 \\
\hline Glucose $(\mathrm{mM})$ & $3.75 \pm 0.24^{\mathrm{a}}$ & $3.76 \pm 0.25^{\mathrm{a}}$ & $3.76 \pm 0.26^{\mathrm{a}}$ & $3.75 \pm 0.24^{\mathrm{a}}$ \\
\hline Total cholesterol (mM) & $2.37 \pm 0.07^{\mathrm{a}}$ & $2.49 \pm 0.05^{\mathrm{b}}$ & $2.58 \pm 0.07^{\mathrm{c}}$ & $2.45 \pm 0.05^{\mathrm{d}}$ \\
\hline Triglycerides (mM) & $0.38 \pm 0.01^{\mathrm{a}}$ & $0.40 \pm 0.01^{\mathrm{b}}$ & $0.41 \pm 0.01^{\mathrm{c}}$ & $0.39 \pm 0.01^{\mathrm{d}}$ \\
\hline Urea $(\mathrm{mM})$ & $8.55 \pm 0.03^{\mathrm{a}}$ & $8.63 \pm 0.02^{\mathrm{b}}$ & $8.68 \pm 0.04^{c}$ & $8.60 \pm 0.02^{\mathrm{d}}$ \\
\hline Albumin (g/dL) & $3.04 \pm 0.16^{\mathrm{a}}$ & $3.63 \pm 0.08^{\mathrm{b}}$ & $4.04 \pm 0.22^{\mathrm{c}}$ & $3.42 \pm 0.10^{\mathrm{d}}$ \\
\hline Total protein $(\mathrm{g} / \mathrm{dL})$ & $8.30 \pm 0.15^{\mathrm{a}}$ & $8.84 \pm 0.12^{b}$ & $9.16 \pm 0.14^{\mathrm{c}}$ & $8.62 \pm 0.14^{\mathrm{d}}$ \\
\hline Sodium ion (mM) & $140.00 \pm 7.77^{\mathrm{a}}$ & $167.02 \pm 3.82^{\mathrm{b}}$ & $186.27 \pm 10.22^{\mathrm{c}}$ & $157.68 \pm 4.75^{\mathrm{d}}$ \\
\hline Creatine kinase (U/L) & $13.07 \pm 0.07^{\mathrm{a}}$ & $13.19 \pm 0.05^{\mathrm{b}}$ & $13.28 \pm 0.07^{\mathrm{c}}$ & $13.15 \pm 0.05^{\mathrm{d}}$ \\
\hline Arginine vasopressin $(\mathrm{pg} / \mathrm{mL})$ & $8.40 \pm 0.10^{\mathrm{a}}$ & $8.52 \pm 0.05^{b}$ & $8.62 \pm 0.09^{c}$ & $8.49 \pm 0.05^{\mathrm{d}}$ \\
\hline Aldosterone (pg/mL) & $26.78 \pm 0.68^{\mathrm{a}}$ & $28.09 \pm 0.64^{\mathrm{b}}$ & $28.96 \pm 0.69^{c}$ & $27.59 \pm 0.63^{\mathrm{d}}$ \\
\hline
\end{tabular}

${ }^{1}$ Data summarised by sheep across all the sampling days; ${ }^{\dagger}$ (Kaneko et al 2008); ${ }^{\S}$ (Lotfollahzadeh et al 2016); ${ }^{\ddagger}$ (Mengistu et al 2016); ${ }^{\text {II }(K a t a r i a}$ and Kataria 2007); *significant differences were obtained between groups indicated with different letters; $* P 00.05$.

Table 3. Pearson Correlation Coefficients for different biochemical analytes of feral sheep from the Socorro Island, Revillagigedo Archipelago, during restricting water intake ( $n=376$ blood serums).

\begin{tabular}{|c|c|c|c|c|c|c|c|c|c|}
\hline & COL-T ${ }^{b}$ & $\mathrm{TAG}^{\mathrm{c}}$ & urea & $\mathrm{ALB}^{\mathrm{d}}$ & PROT-T $^{\mathrm{e}}$ & $\mathrm{Na}^{+\mathrm{f}}$ & $\mathrm{CK}^{\mathrm{g}}$ & AVPh & Aldo ${ }^{\mathrm{i}}$ \\
\hline \multirow[t]{10}{*}{ GLU $^{\mathrm{a}}$} & 0.04 & 0.03 & 0.04 & 0.03 & 0.03 & 0.03 & 0.04 & 0.06 & 0.03 \\
\hline & COL-T & $0.33 *$ & 0.26 & $-0.75^{*}$ & 0.24 & 0.14 & 0.10 & $0.90 *$ & $0.33 *$ \\
\hline & & TAG & 0.14 & $-0.80 *$ & 0.09 & 0.13 & 0.11 & $0.84 *$ & 0.09 \\
\hline & & & urea & 0.14 & $0.80 *$ & 0.09 & 0.20 & $0.82 *$ & 0.19 \\
\hline & & & & ALB & 0.07 & 0.09 & $0.60 *$ & 0.11 & 0.10 \\
\hline & & & & & PROT-T & 0.10 & $0.79 *$ & $0.71 *$ & 0.12 \\
\hline & & & & & & $\mathrm{Na}^{+}$ & 0.19 & 0.13 & $0.76^{*}$ \\
\hline & & & & & & & CK & 0.13 & 0.11 \\
\hline & & & & & & & & AVP & $0.84 *$ \\
\hline & & & & & & & & & Aldo \\
\hline
\end{tabular}

Official abbreviation of the International Union of Pure and Applied Chemistry (IUPAC); ${ }^{\mathrm{a}}$ Glucose; ${ }^{\mathrm{b}}$ Total cholesterol; ${ }^{\mathrm{c}}$ Triglycerides; ${ }^{\mathrm{d}}$ Albumin; ${ }^{\mathrm{e}} \mathrm{Total}$ protein; fSodium ion; ${ }^{\mathrm{g}} \mathrm{Creatine} \mathrm{kinase;}{ }^{\mathrm{h}} \mathrm{Arginine}$ vasopressin; ${ }^{\mathrm{i}}$ Aldosterone; ${ }^{*} P<0.05$ 
two physiological conditions, lactating and dry, over a 3-week-period, and an increase ALB (3.08 vs. $3.43 \mathrm{~g} /$ dL), COL-T (1.7 vs. 2.4 mM), PROT-T (7.39 vs. $7.86 \mathrm{~g} /$ $\mathrm{dL}$ ), and urea (8.29 vs. $10.01 \mathrm{mM}$ ) was observed. Jaber et al (2004) also reported that water restriction increased COL-T (1.90 vs. 2.14 mM), PROT-T (7.59 vs. 8.03 g/dL), and urea (5.96 vs. $7.71 \mathrm{mM})$, and Ghanem et al (2008) reported that COL-T increased (1.61 vs. $2.06 \mathrm{mM}$ ).

The negative correlations $(P<0.05)$ between ALB with COL-T and TAG presented in table 3 , relate to the availability of acetyl-CoA. After its synthesis, the ALB resides in the smooth endoplasmic reticulum and Golgi bodies (Menzies et al 2016). The smooth endoplasmic reticulum is the compartment for lipid synthesis (Black et al 2002). There, the acetyl-CoA molecules are joined together to form COL-T and TAG (Kumar et al 2018). Thus, nascent ALB is expected to cleave the thioester bond of acetyl-CoA (Menzies et al 2016). It is plausible to think that this non-enzymatic acetylation of ALB is possible in the intracellular compartment using acetyl-CoA (Kumar et al 2018) and that this limits the availability of acetylCoA for the synthesis of COL-T and TAG (Morgan et al 2016). Positive correlations $(P<0.05)$ between the different biochemical analytes presented in table 3 relate to two main mechanisms for conserving body water. The first mechanism involves osmoreceptors that detect increases in solute concentrations in the blood during dehydration (Prager-Khoutorsky 2017). These osmoreceptors send a neural signal to the hypothalamic supraoptic nucleus (Gizowski and Bourque 2018), to translate AVP from nine amino acids (aa) (Rotondo et al 2016). AVP stored and released by the neurohypophysis travels to the kidneys, binds to receptors in the distal or collecting tubules, and promotes antidiuresis (retention of water) (Pratt et al 2016), in the loop of Henle and the proximal tubule of the nephron (Bankir et al 2017). Water reabsorption varies, depending on the concentration of circulating AVP, which is usually determined by plasma osmolality, but also intracellular fluid volume (Trepiccione et al 2019). Hence, the serum volume decreases due to water uptake by cells (Trepiccione et al 2019) and COL-T, TAG, urea, PROT-T, and Aldo increase positively in relation to the AVP concentration (table 3 ).

The second mechanism involves baroreceptors that detect low blood pressure and low blood volume (Burlando et al 2019). In response, neurons send a signal to the juxtaglomerular cells of the kidneys to translate renin also called angiotensinogenase (Ames et al 2019), which hydrolyses angiotensinogen to angiotensin I (Patel et al 2017). Angiotensin I, is hydrolysed by the angiotensinconverting enzyme (ACE) forming angiotensin II (Burlando et al 2019), which stimulates the conversion of COL-T to Aldo (mineralocorticoid) in the adrenal gland (Ames et al 2019). Aldo conserves $\mathrm{Na}^{+}$in the renal distal convoluted tubule (Patel et al 2017), as can be seen in figure 3, where the results indicate that Aldo was positively correlated with $\mathrm{Na}^{+}$, triggering reabsorption of water through osmosis. Figure 3 shows the linear regression model for these variables.

The $\mathrm{Na}^{+}$is the dominant extracellular cation and the main determinant of osmolality (Berihulay et al 2019), and therefore of water distribution between the extracellular and intracellular fluid compartments (Burlando et al 2019). This has also been reported by Hamadeh et al (2006) in Awassi sheep. In particular, the progressive increase in Aldo, in response to water restriction, leads to an increase in $\mathrm{Na}^{+}$concentration. Hence, many of the extrinsic regulators of renal function are intended to alter $\mathrm{Na}^{+}$excretion, preserve $\mathrm{Na}^{+}$balance, and regulate blood pressure (Trepiccione et al 2019).

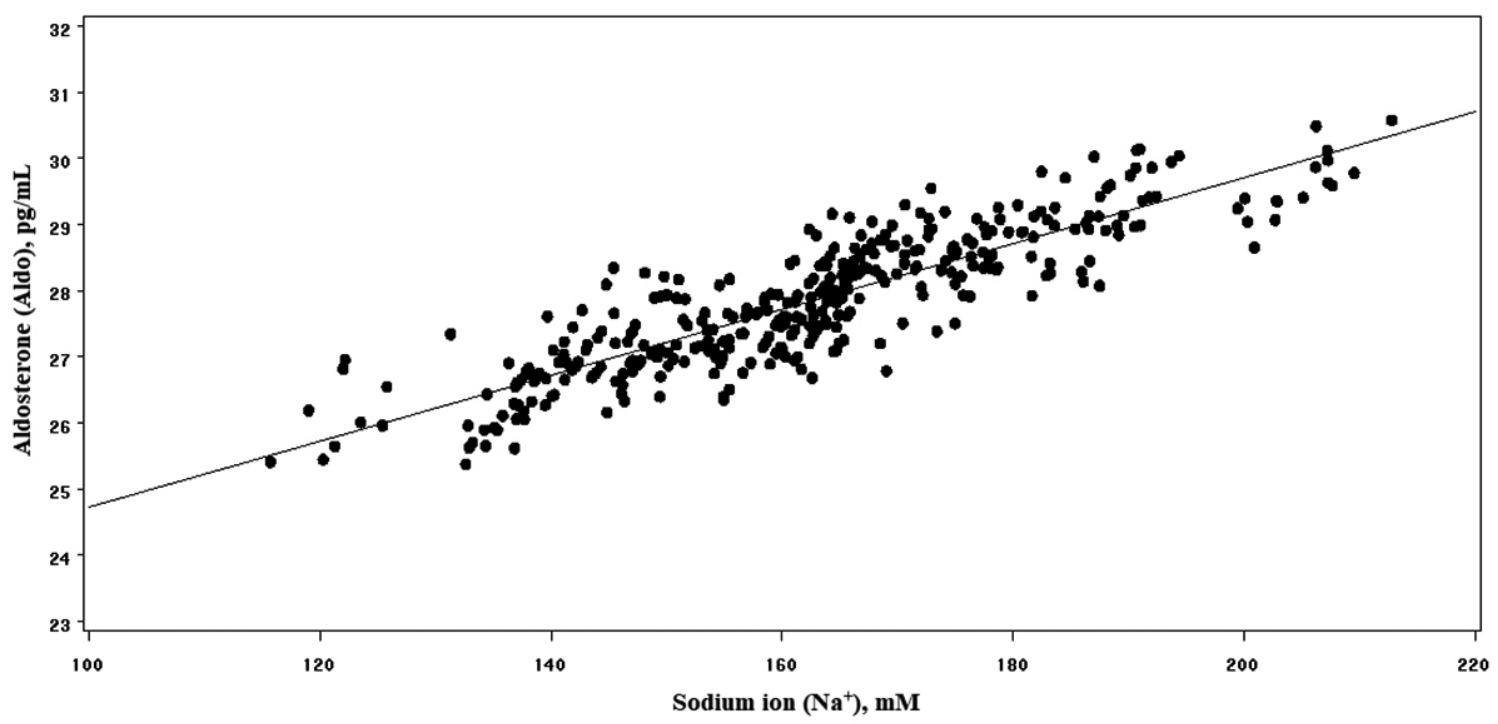

Figure 3. Relationship between aldosterone and sodium ion. Aldosterone $(\bullet)$; predicted response (一). 
The feral sheep from Socorro Island of the Revillagigedo Archipelago needed $21 \mathrm{~d}$ to adapt to water shortage treatment. Results suggested that the feral sheep had high resilience to limited water availability, expressed in the concentration of different biochemical analytes considered as good indicators of dehydration. These results show the important role of water, as a limiting factor for sheep in lowwater availability environments. The Pearson Correlation Coefficients could be used at the herd level, to detect physiological mechanisms to cope with water restriction. Understanding the physiological mechanisms associated to these values would help researchers to select animals that maintain their productive ability under environmental stressors such as drought.

\section{ACKNOWLEDGEMENTS}

This project was supported by the National Council of Science and Technology-México (CONACyT-México) and the project: Metabolic profiles and their implications in veterinary medicine (University of Colima). The authors wish to thank their colleague Carlos Enrique Izquierdo-Espinal for his invaluable assistance.

\section{REFERENCES}

Abdelatif AM, Elsayed SA, Hassan YM. 2010. Effect of state of hydration on body weight, blood constituents and urine excretion in Nubian goats (Capra hircus). World J Agric Sci 6, 178-188.

Ames MK, Atkins CE, Pitt B. 2019. The renin-angiotensin-aldosterone system and its suppression. J Vet Intern Med 33, 363-382.

Bankir L, Bichet DG, Morgenthaler NG. 2017. Vasopressin: physiology, assessment and osmosensation. J Intern Med 282, 284-297.

Berihulay H, Abied A, He X, Jiang L, Ma Y. 2019. Adaptation mechanisms of small ruminants to environmental heat stress. Animals (Basel) 9, 15-21.

Black VH, Sanjay A, van Leyen K, Moeller I, Lauring B, et al. 2002. Cholesterol and steroid synthesizing smooth endoplasmic reticulum of adrenocortical cells contains high levels of translocation apparatus proteins. Endocr Res 28, 425-430.

Burlando B, Blanchini F, Giordano G. 2019. Loop analysis of blood pressure/volume homeostasis. PLoS Comput Biol 15, e1007346.

Casamassima D, Pizzo R, Palazzo M, D'alessandro A, Martemucci G. 2008. Effect of water restriction on productive performance and blood parameters in comisana sheep reared under intensive condition. Small Rumin Res 78, 169-175.

Casamassima D, Vizzarri F, Nardoia M, Palazzo M. 2016. The effect of water-restriction on various physiological variables in intensively reared Lacaune ewes. Vet Med-Czech 61, 623-634.

Flores PA, Martínez GJE, Curry RL. 2009. La vegetación de isla Socorro, archipiélago de Revillagigedo, México. Bol Soc Bot Méx 1, 13-23.

Ghanem AM, Jaber LS, Said MA, Barbour EK, Hamadeh SK. 2008. Physiological and chemical responses in water-deprived Awassi ewes treated with vitamin C. J Arid Environ 72, 141-149.

Gizowski C, Bourque CW. 2018. Hypothalamic neurons controlling water homeostasis: it's about time. Curr Opin Physiol 5, 45-50.

Hamadeh S, Rawda N, Jaber L, Habre A, Said MA, et al. 2006. Physiological responses to water restriction in dry and lactating Awassi ewes. Livest Sci 101, 101-109.

Hernández RJA, Lepe M, Macedo BRJ, Arredondo V, Cortez EC, et al. 2017. Morphological study of Socorro Island Merino sheep and its crosses with hair breeds. Trop Anim Health Prod 49, 173-178.
Jaber LS, Habre A, Rawda N, Said MA, Barbour EK, et al. 2004. The effect of water restriction on certain physiological parameters in Awassi sheep. Small Rumin Res 54, 115-120.

Kaneko JJ, Harvey WJ, Bruss LM. 2008. Appendix VIII Blood Analyte Reference Values in Large Animals. In: Kaneko JJ, Harvey WJ, Bruss LM (ed). Clinical Biochemistry of Domestic Animals. $6^{\text {th }}$ ed. Academic Press, San Diego, USA, Pp 882-888.

Kataria N, Kataria AK. 2007. Compartmental water management of Marwari sheep during dehydration and rehydration. Veterinarski Arhiv 77, 551-559.

Kumar D, Behal S, Bhattacharyya R, Banerjee D. 2018. Pseudoesterase activity of albumin: A probable determinant of cholesterol biosynthesis. Med Hypotheses 115, 42-45.

Lotfollahzadeh S, Zakian A, Tehrani-Sharif M, Watson DG. 2016. Assessment the alterations of some biochemical parameters in Afshari sheep with possible metabolic disorders. Small Rumin Res 145, 58-64.

Mengistu UL, Puchala R, Sahlu T, Gipson TA, Dawson LJ, et al. 2016. Comparison of different levels and lengths of restricted drinking water availability and measurement times with Katahdin sheep and Boer and Spanish goat wethers. Small Rumin Res 144, 320-333.

Menzies KJ, Zhang H, Katsyuba E, Auwerx J. 2016. Protein acetylation in metabolism - metabolites and cofactors. Nat Rev Endocrinol 12, 43-60.

Morgan AE, Mooney KM, Wilkinson SJ, Pickles NA, Mc Auley MT. 2016. Cholesterol metabolism: A review of how ageing disrupts the biological mechanisms responsible for its regulation. Ageing Res Rev 27, 108-124.

Ortiz PR, Alcántara CJL, de la Cueva H, Martínez GJ, Escalante PP, et al. 2016. Avian conservation in Mexico: a 2015 snapshot. Huitzil Rev Mex Ornitol 17, 234-238.

Patel S, Rauf A, Khan H, Abu-Izneid T. 2017. Renin-angiotensinaldosterone (RAAS): The ubiquitous system for homeostasis and pathologies. Biomed Pharmacother 94, 317-325.

Peel MC, Finlayson BL, McMahon TA. 2007. Updated world map of the Köppen-Geiger climate classification. Hydrol Earth Syst Sci 11, 1633-1644.

Pickering NK, Young EA, Kijas JW, Scobie DR, McEwan JC. 2013. Genetic origin of Arapawa sheep and adaptation to a feral lifestyle. Proc Assoc Advmt Anim Breed Genet 20, 451-454.

Prager-Khoutorsky M. 2017. Mechanosensing in hypothalamic osmosensory neurons. Semin Cell Dev Biol 71, 13-21.

Pratt LR, Chaudhari MI, Rempe SB. 2016. Statistical analyses of hydrophobic interactions. J Phys Chem B 120, 6455-6460.

Rotondo F, Butz H, Syro LV, Yousef GM, Di Ieva A, et al. 2016. Arginine vasopressin (AVP): a review of its historical perspectives, current research and multifunctional role in the hypothalamo-hypophysial system. Pituitary 19, 345-355.

Salas de León DA, Monreal GMA, Gracía A, Salas MD. 2015. Two years of oceanographic and meteorological data from the UNAM buoy anchored at Socorro Island in the mexican pacific. Open $J$ Mar Sci 5, 182-192.

SAS. 2001. SAS/STAT User's guide. 8.2 ed. SAS Institute Inc, Cary, NC.

Trepiccione F, Capasso G, Unwin R. 2019. Electrolytes and acid-base: common fluid and electrolyte disorders. Medicine 47, 489-497.

Vosooghi-Postindoz V, Tahmasbi A, Naserian AA, Valizade R, Ebrahimi H. 2018. Effect of water deprivation and drinking saline water on performance, blood metabolites, nutrient digestibility, and rumen parameters in Baluchi lambs. Iran J Appl Anim Sci 8, 445-456.

Weiner ID, Mitch WE, Sands JM. 2015. Urea and ammonia metabolism and the control of renal nitrogen excretion. Clin J Am Soc Nephrol 10, 1444-1458.

Weiner ID, Verlander JW. 2016. Recent advances in understanding renal ammonia metabolism and transport. Curr Opin Nephrol Hypertens $25,436-443$.

Weiner ID. 2017. Roles of renal ammonia metabolism other than in acid-base homeostasis. Pediatr Nephrol 32, 933-942. 
